\title{
The impact of public services outsourcing on work and employment conditions in different national regimes
}

\author{
Anna Mori \\ Università degli Studi di Milano, Italy
}

Corresponding author:

Dipartimento di Scienze Sociali e Politiche, Università degli Studi di Milano, via Conservatorio 7, 20122 Milano. Italy

anna.mori@unimi.it

\begin{abstract}
This article examines the impact of outsourcing of public services on employment relations and working conditions in three countries: Italy, the UK and Denmark. It presents six matched case studies and investigates whether contracting out by public administrations causes a market-driven convergence across national boundaries or whether cross-country differences endure. Though outsourcing blurs the organizational boundaries between public and private sectors everywhere, making terms and conditions of employment fragmented and less protected, distinct structures and legacies of national employment relations institutions result in differences between national trajectories.
\end{abstract}

\section{Keywords}

Outsourcing, public sector, state traditions, new public management, Italy, UK, Denmark

\section{Introduction}

Diminished resources in the aftermath of the sovereign debt crisis together with increased demands for public services put European governments under severe and sustained strain (Glassner, 2010). Public authorities have increasingly focused on the outsourcing of public services, aiming to exploit the competitive advantages of market competition (Savas, 1987) and the less stringent regulation of employment in the private sector (Jaehrling and Méhaut, 2013). This has blurred the boundaries between public and private sector terms and conditions of employment, and triggered fragmentation and inequalities (Flecker and Meil, 2010; Marchington et al., 2004). Public service industrial relations have traditionally remained sheltered from market pressures, ensuring relatively uniform working conditions and job security. Their configuration has primarily represented a political rather than an economic process, regulated by separate institutions from the private sector and with distinct rules, reflecting the unique role played by the state as simultaneously employer, economic regulator, legislator and provider of public services (Bach, 1999). Outsourcing challenges this scenario not only by putting traditionally protected employment relations under major pressure, but also by altering their distinctiveness and opening an insulated decisional arena to new regulatory actors and diverse governance logics.

In this article I examine at how far the outcomes reflect a common market-driven logic as against distinct national institutional arrangements and legislative frameworks. Advocates of 'new public management' in the 1990s (Dunleavy and Hood, 1994) predicted a convergence across European public administrations towards a private sector style of governance, but there has been growing evidence of more mixed and diversified developments across countries (Pollitt and Bouckaert, 2011). Nevertheless, more recent economic constraints and marketization processes newly question the 'enduring variety' argument. I investigate these changes through a focus in recent developments. The interplay between the austerity agenda and outsourcing, potentially an extreme trigger for convergence, provides a privileged test case. Previous literature has focused mainly on financial considerations (Jensen and Stonecash, 2005) and on contractions in public employment (Fernandez et al., 2007). Beyond the elaborate studies that for decades have concentrate on the UK 
(Ascher 1987), a forerunner country in the adoption of competitive tendering in the public sector, scholars have only recently started to include working conditions in their scrutiny of public service restructuring in European countries (Hermann and Flecker, 2012; Mori, 2015).

I commence with a review of the literature on trajectories of reform of public sector employment relations, disentangling the opposing hypotheses of convergence or enduring variety in national models. After introducing the research design, I present empirical evidence from case studies of public services outsourcing in Italy, the UK and Denmark. I focus on changes reported in three clusters of work-related variables: employment status and its fragmentation; wage levels and contractual allowances; and work organization. A concluding section discusses the results comparatively, proposing a refined categorization of national trajectories in public sector employment relations.

\section{Public sector employment relations: Between enduring cross-country variety and market-driven convergence}

Structural peculiarities rooted in state traditions, including national legislative and administrative arrangements, have shaped the institutional configuration in public sector employment relations of each country (Bordogna, 2008). The unique role played by the state as simultaneously employer, economic regulator, legislator and provider of public services has historically underpinned not only the national configurations, but also the distinctiveness of public services employment relations from the private sector (Grimshaw et al., 2007), being regulated by separate institutions and distinct rules (Bach and Bordogna, 2013). As a result, public sector employment relations were sheltered, operating in a relatively closed environment predominantly shaped by the regulatory power of the state and other domestic actors, while market pressures exercised only indirect and marginal influence (Della Rocca, 2013).

Outsourcing upset this equilibrium by blurring the boundaries between public and private sectors and by altering the system of constraints and incentives governing the functioning of public services. This triggered major changes for employment relations, with substantial implications for working conditions (Flecker and Meil, 2010).

Researchers have investigated the trajectories of transformation of public sector industrial relations without reaching a common position. The opposed hypotheses of convergence as against enduring variety in national models animate the debate, mirroring accounts of changes in the private sector (Baccaro and Howell, 2011; Thelen, 2014) dating back to the varieties of capitalism thesis (Hall and Soskice, 2001).

Those who assert persisting variety rely on the explanatory power of national institutional arrangements (Bach and Bordogna, 2013; Traxler, 2003). The nation-state regime remains pivotal in shaping the trajectories of reform in the public sector: 'a blend of the specific features of individual state traditions with their unique administrative cultures; the historical development of the welfare state, incorporating a particular post-war settlement between capital and labour; and the economic and political characteristics of each country have borne strongly on the evolution of public sector employment relations' (Bach, 1999: 2). Country-specific regimes of public sector governance are seen as buffers, mediating the repercussions of economic shocks and organizational restructuring on domestic public services employment relations (Grimshaw et al., 2007). Resilience and adaptability of national models explain institutional capacity to adapt flexibly to major changes along path-dependent trajectories (Pollitt and Bouckaert, 2011), absorbing shocks and resisting transformations potentially corrosive for national models (Ongaro, 2009).

Four main sets of institutional factors underpinning cross-country distinctiveness may cause diversified trajectories following outsourcing. A first major difference relates to the regulatory processes setting terms and conditions of employment in the public sector (Grimshaw et al., 2007). The degree of decisional autonomy by public employers over employment matters ranges from prominent to circumscribed. Different regulatory styles embody such variance: unilateral employer regulation, pay review bodies, collective negotiations subject to government approval and free collective bargaining. Accordingly, the extent of employee voice on employment matters may shape 
more or less advantageous contractual arrangements for public employment and for personnel involved in restructuring processes.

Second, countries vary in the degree of employment protection, career security and prerogatives derived from the status of public employee (Della Rocca, 2013). The strength of the institutional constraints sheltering a public employee's job and status mediate differently the implication of marketization processes over terms and conditions of employment, preventing or mitigating detrimental repercussions.

Third, national systems vary according to the extent of the public-private sector gap in industrial relations institutions and contractual arrangements, as well as the institutional intersection between the two sectors (Grimshaw et al., 2015). Outsourcing opens up public sector boundaries to private sector regulatory mechanisms: the more pronounced the differences between the two, the less institutions and actors in the two segments of the labour market will cooperate to set terms and conditions of employment in outsourced services. Diverse paths can follow, given that major divides can be exploited by public employers to reduce labour costs (Jaehrling and Méhaut 2013). The different degree of collective bargaining coverage between the two sectors, the diverse relevance of trade unions and the variation in union density act as mediators between market pressures and labour dynamics.

Fourth, countries differ in the procurement systems regulating the relationships between the government and its contractors. These include legal obligations to incorporate social and employment clauses in calls for tender and the implementation of Transfer of Undertakings (TUPE) regulations. Diverse combinations of these dimensions lead to different configurations across countries, more or less employee-friendly according to the limitations these regulatory constraints impose on job deterioration during restructuring. The different configurations of the national procurement systems can be 'market-making' or 'market-embedding' (Jaehrling 2015).

By contrast, those identifying public sector convergence towards private sector governance within each country (and possibly between public sectors across countries) assume the pervasiveness of a common neoliberal trajectory. Virtually every Western government since the 1980s has sought to modernize its public administration, in response to common pressures identified in increasing public debt also following the financial crisis, with critiques of inefficiencies in public administration and citizens' demands for higher quality and customized public services. The common response involved a multidimensional two-level doctrine aimed at reducing or removing any difference between the public and private sectors (Dunleavy and Hood, 1994). The theoretical construct rooted in the new institutional economics --- in particular transaction costs, agency and public choice theories --centred on applying business concepts, values and disciplines from the private sector. At the operational level it translated into a set of market-oriented mechanisms of governance combined with private sector practices of labour regulation (Hood, 1991).

The soon popular concept of 'new public management' (NPM) implied uniformity and communality. Given the claim to universality, NPM-inspired trajectories of reform were expected to cause convergence in public sector models across countries and convergence between public and private sectors within each country. Maxims such as 'disaggregation, competition, incentivization and marketization' (Dunleavy and Hood, 2004) entailed the redesign of the boundaries between the sectors in both organizational and functional terms. With regard in particular to employment relations, an analogous dual convergence was postulated. Following such institutional restructuring, public service industrial relations should also become increasingly alike across countries, with the national arena no longer paramount as industrial relations structures evolve in response to both domestic and international challenges.

Evidence for convergence is provided by the outsourcing of public services, which crucially alters the organizational structure of public services, blurring the boundaries between public and private sectors, overlapping terms and conditions of employment (Hermann and Flecker, 2012). Outsourcing is regarded as an effective policy tool for reducing the cost of services and making their provision more flexible, by virtue of market competition (Savas, 1987). Nevertheless the model of competition it promotes is often largely based on the reduction of labour costs through reduced public employment or a deterioration in working conditions (Flecker and Meil, 2010). Accordingly, the transformation in industrial relations structures under outsourcing implies a uniform slide towards a liberalization pattern which adversely affects the distributive outcomes associated with these 
institutions, including a deterioration of working conditions, a fragmentation of employment, a rise in job insecurity and growing flexibility (Marchington et al., 2004). Moreover, the public-private sector gap in employment regulation is shrinking. Public employers may benefit from the less stringent regulation of employment in the private sector, by circumventing the protective and encompassing set of norms regulating public services, ratcheting protections down towards private sector standards, and shifting jobs from highly unionized public organizations towards private contractors where industrial relations institutions are weaker (Jaehrling and Méhaut, 2013).

\section{Methods and case description}

To address these conflicting assessments of the employment relations consequences of outsourcing, in 2013 and 2014 I undertook research in Italy, the UK and Denmark. Given their distinctive state traditions and models of governance of public service employment relations, this represents a 'most different case' design. Key features are summarized in Table 1.

[Table 1 about here]

Italy has a long tradition of state intervention in defining procedural rules for collective bargaining, as well as in the actual negotiations for public employees. Public employee status provides greater job protection than in the private sector, alongside generally more favourable terms and conditions of employment. Union density is higher in the public sector (50 percent) than in the private (30 percent), and collective bargaining coverage is 100 percent as against 74 percent in the private sector.

The UK possesses a liberal regime which puts emphasis mainly on market adjustments and self-regulation, minimizing the role of collective bargaining and organized labour institutions, which are seen as negative rigidities. In contrast to most European countries, there is no clear legal distinction between industrial relations institutions in the public and private sectors, and public employees enjoy few special prerogatives attached to their status. There is a huge gap in union density between public (55 percent) and private (14 percent) sectors, associated with much higher collective bargaining coverage (64 percent as against 17 percent).

Denmark typifies the Nordic industrial relations regimes, with inclusive regulation and policies designed to maximize employment and provide comprehensive employment rights. The system provides welfare and high protection to all workers, minimizing differences within the labour market. Organized labour has a strongly institutionalized role, backed by a very high union density in both the public ( 83 percent) and the private ( 65 percent) sectors, interacting with employers' associations for a relatively universalized protection of terms and conditions of employment through collective agreements that cover the whole public personnel and 74 percent of the private sector workforce (European Commission, 2013).

Such national differences in employment relations systems and institutional frameworks help to shape market-driven transformations, absorbing economic and organizational shocks and adapting to major changes. In particular, the effects of outsourcing can be mediated by the forms of labour market regulation, the strength of industrial relations institutions and the coverage collective agreements, as well as the extent to which regulatory processes extend job protections to both public and private sectors and the institutional interplay between the two (Jaehrling, 2015). The comparison among three 'most-different' models enables a better appreciation of the influence of national institutional frameworks interacting with similar market forces. In Italy and Denmark, extensive labour market regulation and strong collective bargaining structures may act as buffer in alleviating and controlling the negative impacts of restructuring. Conversely, in the UK a more liberal tradition which restricts the role for collective employment regulation and organized labour institutions might facilitate detrimental consequences for labour, making public employment more similar to private.

For my comparative analysis of outsourcing in public services I selected two matching cases from each country, in the municipal and healthcare sectors respectively. All cases involved a farreaching use of outsourcing in a wide array of public services. The research design helped to pinpoint regularities in the systemic developments of employment relations configurations, excluding 
exceptional outcomes and outliers. An extensive implementation of contracting out, involving a variety of tasks in labour-intensive services, should reinforce the reliability of findings by confronting evidence from distinct processes, stressing once again systemic regularities. The empirical investigation focused primarily on the first round of subcontracting for each service, monitoring subsequent rounds when relevant in terms of implications over working conditions.

The research involved 75 semi-structured interviews ( 25 in Italy, 24 in the UK, 26 in Denmark) complemented by documentary analysis. Data collection was divided into two phases within each country. The first part of the research focused on the national level: interviews with key stakeholders and document collection provided a first overview of the phenomenon in the country and laid the foundations for the selection of the six cases. The second step involved analysis of each case at local level, conducted through interviews with key informants on the employer side (councillors and mayors in the municipalities, local representatives from employers' associations, managers and administrative staff in procurement departments, HR department managers); the trade union side (union officials in local branches and shop stewards) and external experts. These expert interviews were based on a semi-standardized set of topics, covering a detailed description of the outsourcing process; main actors and stakeholders involved; changes in employment status and work organization; redundancy and dismissal procedures; application of collective agreements and employment protections; variations in pay and contractual allowances; use of social clauses. All the interviews were recorded, transcribed and content analysed. Documentary analysis of secondary sources (collective agreements, media debates, legislation, internal papers and academic literature) complemented the analysis. Validity was gained through triangulation of sources, interviewing actors from multiple sides of the process.

\section{Case study evidence}

The six public administrations under study, formerly unitary structures providing all the public services internally, now host a multiplicity of employment arrangements within their organizational boundaries. The overall picture involves patchy trajectories on all three main dimensions considered in the research. Three clusters of employment-related factors proved to be particularly targeted by outsourcing: employment status; wages and contractual allowances; and organization of work. The key changes are summarized in Table 2.

[Table 2 about here]

\section{Impact on employment status}

The degree to which outsourcing of public services has changed the status of employees varies across the three countries.

In Italy, the large majority of public personnel were relocated internally, despite the law of 2001 allowing public administrations to outsource employees or to impose redundancy and mobility procedures in case of staffing surpluses. Redundancies were avoided. In the municipality, gardeners and maintenance workers were redeployed to the local council office for environment and urban infrastructures; ancillary tasks like document delivery and security were entrusted to cleaning staff when cleaning was outsourced, while personnel in charge of social and educational services (including nurses, kindergarten teachers and social workers) maintained their roles, complementing the staffing provided by the external contractors. In the hospital, cleaning staff were retrained and placed at disposal of the wards to carry out manual requirements; stretcher bearers and porters kept their function, as did security employees.

Because the duration of the contract was provisional, contractors' employees did not enjoy the full employment protection attached to the status of permanent public employee. Accordingly, only a small proportion of personnel was transferred to private companies: the shift in status in the municipality affected less than a dozen workers in graveyard management, a few workers in parks 
maintenance and temporary catering staff. In the hospital, only temporary staff employed in the kitchens transferred to the cooperative taking over as service provider.

A further trajectory of change involved external secondment of public employees to private companies. They retained their public status, and the definition of contractual arrangements has remained a prerogative of the public employer; but the private providers were entitled to set job content and organization for seconded staff. Nevertheless the adoption of secondment was negligible, involving only the municipal permanent staff in catering and hospital workers in the laundry unit.

Conversely in the $U K$, both cases displayed massive transfers of public staff to private subcontractors, accompanied by sizeable redundancies. In the local authority the very first calls for tenders in street cleaning and refuse collection contained a negotiated non-redundancy agreement for staff involved, through redeployment within the public administration, transfer to private companies, generous early retirement schemes or severance terms, but these remained unique cases of a 'soft touch' approach. In most of other activities subcontracted, such as parks maintenance, council buildings maintenance, sports and leisure centres management, outsourcing has led to the transfer of the whole public staff to the external company, which often proceeded with collective redundancies. Furthermore, severance terms became increasingly less attractive, rapidly reduced to the national legal minimum requirement.

The application of the Transfer of Undertaking (Protection of Employment) (TUPE) legislation to public sector restructuring prevented further redundancies in some services, but not staff transfers. A second major wave of outsourcing involved ICT services, payroll and municipal libraries whose staff have been mainly redeployed to external contractors, shifting from public to private status. Likewise, the outsourcing of ancillary services in the hospital led to a full transfer of staff in cleaning, catering, waste management, laundry services, porters and building maintenance to private subcontractors, where some redundancies were reported during the re-tendering procedures once the first contract expired. However, the externalization of white-collar and clinical services displayed a smoother pattern. Of 25 employees in payroll and recruitment, twenty were relocated within hospital offices while the remaining five were transferred out. Where outsourcing involved clinical services such as rehabilitation, the whole professional body was seconded to the external companies, keeping their public status and the same terms and conditions of employment.

In Denmark the outsourcing of public service has triggered a smooth and dynamic transition of the workforce across organizational boundaries in both directions. Public staff were wholly transferred out during outsourcing and taken back in-house when services were (in some cases, mainly for organizational reasons) insourced again. In the municipality this pattern translated into a shift from public to private status following the transfer to external contractors (600 municipal employees in social and welfare services, 150 cleaners, 20 gardeners, 12 road maintenance workers and about 100 workers in the job centres who, at a later stage, were all insourced again). In the hospital this applied to three windows cleaners, 50 workers in catering, 22 gardeners and 100 cleaners, the latter then all taken back in-house, together with the cleaning service.

Redundancies were rarely implemented, restricted to private companies where public staff were previously transferred. This occurred in the municipality once the public sector collective agreement expired, at the time of negotiating a new private sector collective agreement for a very limited proportion of cleaners, nurses and maintenance workers.

\section{Changes in wages and contractual allowances}

A second set of changes associated with public services outsourcing is the redefinition of wage levels and contractual allowances. Major differences in the regulatory framework and labour institutions emerged following the shift from the public to the private sector. Again the three countries displayed diverse scenarios in this regard.

In Italy the retention of public employee status has guaranteed continuity in the application of public sector collective agreements, preserving same wage rates and contractual allowances, including sick pay, holidays, maternity leave and pensions, for all staff who were internally redeployed. An exception to this contractual stability concerned temporary public employees who, once transferred to the private sector collective agreements, experienced a variation in salary rates and allowances, but 
not necessarily a worsening. The collective agreement for the tourism industry, applied to outsourced staff in catering, did entail a drop in hourly pay and a decline in benefits compared to those in local government and healthcare sector agreements. However, the new collective agreement for private sector staff in environmental services and graveyard maintenance did prove more advantageous than the previous one. Overall, staff remained covered by collectively negotiated contracts, both public employees in services outsourced and those employed by private contractors. Social clauses were included in all the calls for tender, requiring bidding companies to apply the private sector collective agreements applicable to staff employed in outsourced services.

The gap in terms and conditions of employment between public and private sectors has paved the way for the institutionalization of a two-tier (or even multi-tier) workforce at workplace level. Catering in the hospital for instance is supplied by staff with extremely segmented contractual arrangements: these include public employees, public personnel seconded to the private provider, public staff transferred out and private employees recruited by the company. Likewise in the municipality, social services and kindergartens are run by a public and private workforce with the same educational background, performing the same activities but paid at diverse wage rates according to the nature of the employers. Private providers regularly applied contractual arrangements less advantageous for the workforce compared to the public sector.

In the $U K$, the scenario is more unstable and patchy, as far as changes in wages and contractual allowances are concerned. Following outsourcing, detrimental consequences, including a sharp decline in pay rates and the erosion of sick pay, holidays and maternity leave, were experienced by the numerous blue-collar staff transferred out during the first wave of subcontracting in the municipality.

Nevertheless, the weak application of TUPE legislation by the public administration during the second wave of outsourcing altered the pattern, raising employment protection during restructuring. In those cases, public staff was transferred with the same terms and conditions of employment. Public sector collective agreements remained in force until their expiration, as occurred to professional and clerical staff involved in ICT services, payroll, council tax collection and library management. In the hospital, TUPE protections were complemented by the 2004 Agenda for Change (AfC) tripartite agreement which introduced a harmonized grading and pay system for all staff in the healthcare sector. TUPE legislation however ensured continuity in wage levels only as long as the existing collective agreement remained valid. Once it expired, lower standards were generally applied through private sector agreements and unilateral definition of the new terms and conditions of employment set by private subcontractors. Calls for tender did not contain any social clause imposing the application of minimum employment standards beyond those set by such legislation as the National Minimum Wage.

In such a fragmented and poorly protective regulative framework, the institutionalization of a two-tier workforce at workplace was extremely widespread in both cases. Another change triggered by outsourcing concerned the pension schemes, which were not covered by TUPE protections. For most municipal and hospital staff, the transfer to private companies translated into drastic cuts in pension allowances. Given the magnitude of the problem, in 2013 the Treasury revised the 1999 'Fair Deal for Staff Pensions' establishing that members of a public pension scheme compulsorily transferred out remain eligible, ensuring continuity. The efficacy of this legislation was marginal, given that public administrations had wide discretion on membership in their pension schemes. The municipality only accepted as 'admitting body' the company supplying library services, while only professional and clerical staff were authorized to retain membership within the hospital pension scheme.

Denmark showed a third trajectory in wage rates and contractual arrangements. Despite the transitions between public and private status, and the consequent variation in the application of collective agreements, terms and conditions of employment remained almost unaltered, displaying continuity and stability. Such a pattern was possible by virtue of the application of TUPE regulations combined with the long-standing tradition of collective bargaining, taking place every second or third year in both public and private sectors, where agreements have a remarkably high level of coverage. In addition the pay adjustment scheme, linking wage movements in the public sector to those in the private sector as a means to ensure over the long term the same wage trends in the whole economy, has guaranteed broadly similar conditions in the two sectors. 
This institutional infrastructure guaranteed overall stability in pay rates for transferred staff. However it did not prevent a moderate levelling down of further allowances negotiated in the private companies, in particular as regards overtime, holidays, pensions and sick pay. That was the case for gardeners, cleaners and catering staff in both the municipality and the hospital. Conversely, the private sector collective agreement for nurses in social and welfare services sets better conditions than in the public sector.

\section{Work organization and flexibility}

In terms of the impact of outsourcing on work organization, changes occurred differently across the three countries, but overall the trend involved an intensification of work.

In Italy, the transfer to private contractors brought an increase in workload. In the municipality, the company supplying catering intensified the work for both transferred and seconded public staff: the latter in particular experienced a sharp increase in working hours to compensate for working time reductions applied to the former. In the hospital, pressures to raise the speed and load of work were reported by stretcher bearers and porters: the private provider did not replace retired workers but allocated additional tasks, longer shifts and overtime to a shrinking workforce. In catering, staff transferred to an external provider were also subject to increased workloads.

While changes in workload affected only a limited proportion of public personnel in Italy, in the $U K$ work intensification was frequent, affecting especially the staff transferred in municipal services. Staff in waste collection, roads and parks maintenance were subject to longer working hours in order to provide services in a wider area, also outside the municipality, and with the travel time not computed as job time. Nurses providing domiciliary care had to work longer shifts and visit more patients in the same amount of time to prevent a cut in daily wages, since the travel time between patients was not paid by the private contractors. In the hospital the picture was similar.

Increased workloads were also widespread in Denmark. The speed of work increased for cleaning staff moved to private companies. The private sector collective agreement in both local government and healthcare set out a specific space/time ratio to follow during cleaning activities that was higher than the pace negotiated in the public sector. Moving to the private sector meant, for nurses in domiciliary care, an increase from five to eight patients to visit per hour. Transferred gardeners were required to work longer hours, to cover a wider area, as well as to travel more during their shifts.

A second set of changes in work organization concerned job flexibility. Outsourcing of public services has led to a fluctuation in working hours and to higher mobility between workplaces.

In Italy, external secondment by the public administrations allowed private companies to manage public personnel flexibly, as in the case of catering. On the whole, however, private personnel bore the brunt of flexible employment practices. A prominent example is the case of nursery and elderly home care, where the staffing levels varied according to citizens' demand for these services. Outsourcing was exploited to adapt staffing levels flexibly to work needs.

In the $U K$, by contrast, public employees were also subject to increasing flexibility. The manual workforce transferred out by the municipality experienced detrimental consequences, with unions reporting greater incidence of part-time work, connected with flexibility of hours determined by the employer, greater mobility and greater incidence of weekend and evening working.

A similar pattern occurred in Denmark. In the hospital, gardeners were subject to increased flexibility in contractual arrangements, especially through seasonal contracts. Moreover longer shifts were imposed by the private company, which excluded travel time from the computation of working hours in exchange for a fixed rate paid for each kilometre travelled.

\section{Enduring variety of national regimes in public sector employment relations}

The case studies of public services outsourcing in three different national legislative and administrative frameworks reveal diversity in the impact on working conditions and employment relations structures. My main argument is that the trajectories of change following restructuring are 
shaped by specific national institutional configurations and employment relations regimes (Hermann and Flecker, 2012; Vraengbæk et al., 2013). Empirical evidence highlights the complexity and the resilience of state traditions in public service employment relations when subject to market-like pressures of a similar kind (Bach and Bordogna, 2013).

The findings contribute to the debate on enduring variety in public sector employment regimes, and support the thesis of the persistence of different national models. Country-specific models evolve along path-dependent trajectories in response to common neoliberal pressures triggered by NPM-inspired reforms, the austerity agenda and marketization of public services (Grimshaw et al., 2015).

The overall picture in Italy reflects apparent employment stability and security for public personnel: the large majority have been redeployed within the public organization on the same terms and conditions of employment. Negative repercussions for employment status and working conditions were limited to temporary staff who did not enjoy the full job protections attached to the status of permanent public employee. The private sector workforce bore the brunt of cost containment: private providers cut their labour costs by applying inferior collective agreements compared to the public contract, in terms of both wage levels and contractual allowances. This dualism reflects the structural traits of the Italian regime of employment relations: a highly protective employment regime set by legislation for public personnel, strengthened by a tradition of strong unionism in the public sector, as against lower protections, less stringent employment regulation and less encompassing unions in the private subcontractors. The institutionalization of a two-tier workforce within public organizations is largely consistent with the national industrial relations tradition.

Conversely, public employment in the $U K$ has been subject to remarkably detrimental consequences in terms and conditions of employment and job organization following a wholesale transfer of personnel from the public sector to private subcontractors, often ending up with collective redundancy procedures. The shift across organizational boundaries (which have become increasingly blurred) has further eroded the already weakened employment relations structures in the public sector. Following outsourcing, employment standards for public personnel were levelled down (worse working conditions, lower wage rates, reduced contractual allowances, more flexibility, increased job insecurity) to match those in the private sector. Such outcomes mirror a tradition of employment relations where emphasis is placed on market adjustment and self-regulation, where sporadic voluntary relations between social partners prevail, and where the interference of collective regulation, seen as negative rigidity, is minimal. The discretionary implementation of TUPE protections reflects the prevalence of voluntary relationships in the definitions of contractual arrangements, often translated into unilateral employer regulation, over collectively negotiated agreements and state interference.

Denmark displays a distinct third pattern. On the whole public staff, experienced continuous transfers between organizations --- from public administration to private companies, between external providers, as well as from the private sector back to the public --- which led to transformations in their status and accordingly in terms and conditions of employment. Nevertheless, potentially detrimental consequences have been avoided through a longstanding resilient tradition of collective negotiation of widely encompassing contractual arrangements between social partners, designed to extend employment protections as largely as possible, minimizing inequalities across the whole labour market. Further coordinating mechanisms intervened in buffering market challenges and minimizing the difference between public and private sectors, such as pay adjustment schemes linking wage movements across the whole economy, the application of TUPE legislation and the use of systematic information and consultation mechanisms at workplace level.

\section{Conclusions}

The degree of difference between national outcomes stands as a remarkable tribute to the mediating effect of different state traditions (Pollitt and Bouckaert, 2011) in accommodating analogous domestic and external pressures. In particular, country-specific regimes function as self-referential systems (Traxler, 2003), employing path-dependent adaptive processes that perpetuate variety in response to 
most recent pressures to convergence towards a common neoliberal trajectory, driven by cost containment, austerity measures and marketization practices by outsourcing in public services.

Consistent with previous literature on cross-country variety, the resilience and the complexity of state traditions certainly contribute to explaining enduring variation across countries (Bach and Bordogna, 2013). The role played by the state remains relevant in shielding industrial relations from the disintegrating effect of market forces (Jaehrling, 2015), in conjunction with specific legal protections and prerogatives attached to public employment (Della Rocca, 2013). Nevertheless, the findings make it possible to qualify and nuance such arguments. The main explanatory factor lies in the structure of collective bargaining, which remains specific to distinct national models. The coverage of collective agreements, the institutional configuration of the interplay between public- and private-sector collective bargaining, the significance of trade union action and the degree of coordination between social partners crucially determine the consequences of market-driven transformations through outsourcing.

Phrased differently, collective bargaining configurations set boundaries which constrain HR practices to a varying extent. Highly coordinated and encompassing systems, as in Denmark, curb employers' discretion in personnel management, ensuring uniform treatment and stability, more than liberal regimes like the British, where collective bargaining is weak and marginal. Within such boundaries, public authorities and private contractors have a certain leeway to design their strategies, while they may also explain how these boundaries can be stretched and circumvented. The rise in the workload is a telling example of how employers exploit loopholes in collective regulation of labour, avoiding institutional constraints (Jaehrling and Méhaut, 2013).

Consistent with national regimes, implications of outsourcing on terms and conditions of employment turn out to be highly differentiated across the three countries, especially concerning:

- the deterioration in terms and conditions of employment, particularly in the UK;

- labour market segmentation, leading to fragmentation and inequalities, which affected above all the private sector workforce in Italy and the whole personnel in the UK;

- redundancy and dismissal procedures, applied largely in the UK and to a limited extent in Denmark.

This article provides further corroboration of the distinctiveness of trajectories of change in national models of public sector employment relations in an era of austerity and marketization.

Well-established categories cluster national models either by investigating the public sector dynamics in isolation, as governed separately from the private sector (Della Rocca, 2013), or by scrutinising the configurations in the two sectors comprehensively, treating them as a unique arena (European Commission, 2013). These categories are unsatisfactory when the transformation in employment relations jointly and mutually affects both sectors, possibly developing diverse styles within national boundaries. Focusing on distributive outcomes in terms of working conditions, employment structure and protections across public and private sectors, the countries under investigation seem to fit appropriately the three ideal-types theorized by Thelen (2014): Italy as example of dualization, the UK of deregulation and Denmark as model of embedded flexibilization. Starting from the holistic assumption that industrial relations institutions respond overall to domestic and exogenous pressures by following a liberalization trajectory --- an expansion of market relations in areas that were previously reserved to collective political decision-making (Thelen, 2014) --- such categories complement and fine-tune the traditional classification that clusters Italy in the statecentred group, the UK in the liberal one and Denmark in the organised corporatism model (European Commission, 2013: 47).

Dualization differentiates employment protections and collective regulation mechanisms across the labour market, guaranteeing strongly protected employment conditions for a core group of 'insiders', while an expanding periphery of 'outsiders' is allowed to developed unregulated and unorganized, with inferior status and inferior working conditions. Italy clusters in this group, given the gap in industrial relations institutions and the different degrees of employment protection between public and private sectors, that ultimately led to the institutionalization a two-tier workforce. The public personnel respond to an 'insider-like' regulatory framework characterized by higher union density, higher collective bargaining coverage, as well as more protected conditions of employment than the private workforce, which by contrast is subject to an 'outsider-like' employment regime, including lower protections, job instability and worse working conditions. Deregulation involves the 
substitution of institutions and practices of collective regulation of employment in favour of a pure market logic in the definition of terms and conditions of employment. The UK regime matches this schema: outsourcing triggers an overall deterioration in terms and conditions of employment for the whole personnel, setting aside collective mechanisms of labour regulation in favour of market governance in both sectors. Embedded flexibility promotes market-embedding mechanisms in order to expand social policy and employment protections to all the labour market segments, especially those who are weaker and more subject to market-led inequalities. In Denmark, flexibility in public personnel governance is pushed by the market and embedded in the system through solidaristic forms of coordination, where collective bargaining dynamics interact with and mutually reinforce a system of universal social protections and a sustainable model of public procurement, ensuring high and uniforms terms and conditions of employment in both sectors.

In conclusion, it is important to note certain caveats and directions for future research. Most obviously it would be useful to explore further the impact of outsourcing on changes in employment relations in diverse institutional frameworks in order to reinforce, or possibly challenge with strong evidence the enduring variety hypothesis which I have presented. There are also question marks concerning the generalizability of the findings, given that the results are drawn from a limited number of case studies. Despite a careful selection of matching comparable cases, to a certain degree representative of their national contexts, any presumption of general applicability should be taken cautiously. In addition, the sectorial variety within countries worth deeper investigation, consistent with analysis in the private sector (Bechter et al., 2012).

\section{Acknowledgments}

My thanks to the editor and the two anonymous reviewers for their constructive comments. I am grateful to Lorenzo Bordogna who supervised my $\mathrm{PhD}$, from which the article is drawn. I am particularly grateful to Paul Marginson and Guglielmo Meardi whose feedbacks helped me to improve the article.

\section{Funding}

This research received no financial support for the research, authorship, and/or publication of this article.

\section{References}

Ascher K (1987) The politics of privatisation: Contracting out public services. London: Macmillan Education.

Baccaro L and Howell C (2011) A common neoliberal trajectory: The transformation of industrial relations in advanced capitalism. Politics \& Society 39(4): 521-563.

Bach S (1999) Europe: Changing public service employment relations. In: Bach S, Bordogna L, Della Rocca G and Winchester D (eds) Public service employment relations in Europe: Transformation, modernization or inertia? London: Routledge, pp. 1-17.

Bach S and Bordogna L (2013) Reframing public service employment relations: The impact of economic crisis and the new EU economic governance. European Journal of Industrial Relations 19(4): 279-294.

Bechter B, Brandl B and Meardi G. (2012) Sectors or countries? Typologies and levels of analysis in comparative industrial relations. European Journal of Industrial Relations 18(3): 185-202.

Bordogna L (2008) Moral hazard, transaction costs and the reform of public service employment relations. European Journal of Industrial Relations 14(4): 381-400.

Cunningham I and James P (2009) The outsourcing of social care in Britain: What does it mean for voluntary sector workers? Work, Employment and Society 23(2): 363-375. 
Della Rocca G (2013) Employment relations in the public services: Between hierarchy and contract. In: Arrowsmith J and Pulignano V (eds) The transformation of employment relations in Europe: Institutions and outcomes in the age of globalization. London: Routledge, pp. 51-68.

Dunleavy P and Hood C (1994) From old public administration to new public management. Public Money and Management 14(3): 3-19.

European Commission (2013) Industrial Relations in Europe 2012. Luxembourg: Publications Office of the European Union.

Fernandez S, Smith CR and Wenger JB (2007) Employment, privatization, and managerial choice: Does contracting out reduce public sector employment? Journal of Policy Analysis and Management 26(1): 57-77.

Flecker J and Meil P (2010) Organisational restructuring and emerging service value chains: Implications for work and employment. Work, Employment \& Society 24(4): 680-698.

Glassner V (2010) The public sector in the crisis. Brussels: ETUI working paper 2010.07.

Grimshaw D, Jaehrling K, van der Meer M, Méhaut P and Shimron N. (2007) Convergent and divergent country trends in coordinated wage setting and collective bargaining in the public hospitals sector. Industrial Relations Journal 38(6): 591-613.

Grimshaw D, Rubery J, Anxo D, Bacache-Beauvallet M, Neumann L and Weinkopf C (2015) Outsourcing of public services in Europe and segmentation effects: The influence of labour market factors. European Journal of Industrial Relations 21(4): 295-313.

Hall PA and Soskice D (eds) (2001) Varieties of capitalism: The institutional foundations of comparative advantage. Oxford: Oxford University Press.

Hermann C and Flecker J (2012) Privatization of public services: Impacts for employment, working conditions, and service quality in Europe. London: Routledge.

Hood C (1991) A Public Management for All Seasons? Public Administration 69(1): 3-19.

Jaehrling K (2015) The state as 'socially responsible customer'? Public procurement between marketmaking and market-embedding. European Journal of Industrial Relations 21(2): 149-164.

Jaehrling K and Méhaut P (2013) Varieties of institutional avoidance: Employers' strategies in lowwaged service sector occupations in France and Germany. Socio-Economic Review 11(4): 687-710.

Jensen PH and Stonecash RE (2005) Incentives and the efficiency of public sector-outsourcing contracts. Journal of Economic Surveys 19(5): 767-787.

Marchington M, Grimshaw D, Rubery J and Willmott H (eds) (2004) Fragmenting work: Blurring organisational boudaries and disordering hierarchies. Oxford: Oxford University Press.

Mori A (2015) Outsourcing public services: Local government in Italy, England and Denmark. In Drahokoupil J (ed.) The outsourcing challenge: Organizing workers across fragmented production networks. Brussels: ETUI, pp. 137-155.

Ongaro E (2009) Public management reform and modernization: Trajectories of administrative change in Italy, France, Greece, Portugal and Spain. Cheltenham: Edward Elgar.

Osborne D and Gaebler T (1992) Reinventing government: How the entrepreneurial spirit is transforming the public sector. New York: Addison-Wesley.

Pollitt C and Bouckaert G (2011) Public management reform: A comparative analysis - new public management, governance, and the neo-weberian state. Oxford: Oxford University Press.

Savas ES (1987) Privatization: The key to better government. Chatham: Chatham House.

Thelen K (2014) Varieties of liberalization and the new politics of social solidarity. New York: Cambridge University Press.

Traxler F (2003) Bargaining, state regulation and the trajectories of industrial relations. European Journal of Industrial Relations 9(2): 141-161.

Vrangbæk K, Petersen OH and Hjelmar U (2013) Is contracting out good or bad for employees? A review of international experience. Review of Public personnel Administration 20(10): 1-21.

\section{Author biography}

Anna Mori is a researcher at the University of Milan. 


\section{Table 1. Overview of key national regulatory and institutional features}

Italy

Public employee status

Definition of terms and conditions of employment in the public sector

Services outsourced

Public employee consultation

\section{TUPE}

implementation

Social clauses
Greater job protection, more favourable terms and conditions of employment

Legislation defining rules for collective bargaining. Collective negotiation between trade unions and national agency representing public employers.

Both peripheral (cleaning, catering, park maintenance, waste collection) and core (elder care, nurseries, social assistance).

Employee representatives always informed before outsourcing.

Stringent application during public sector restructuring processes.

Public administrations include social clauses in calls for tender.
UK

Denmark

Few prerogatives attached to the status

Public employee status similar to private sector.

Voluntary collective bargaining and increasing unilateral definition by public employers.

First wave: street cleaning, waste collection, park maintenance, catering. Second wave: domiciliary care, ICT services, payroll, libraries, leisure centres, HRM.

Discretionary decision of public administrations to consult employees.

Applied since 1993 in the public sector and just to the first tendering round. Discretionary.

Discretionary decision of public administration to include social clauses.
Collective bargaining between trade unions and public employer organizations. Limited influence of legislation.

Both peripheral (cleaning, catering, park maintenance, waste collection) and core (domiciliary care, social assistance).

Employee representatives always informed and consulted before outsourcing.

Stringent application during public sector restructuring processes.

Public administrations include social clauses in calls for tender. 
Table 2. The impact of outsourcing on terms and conditions of employment

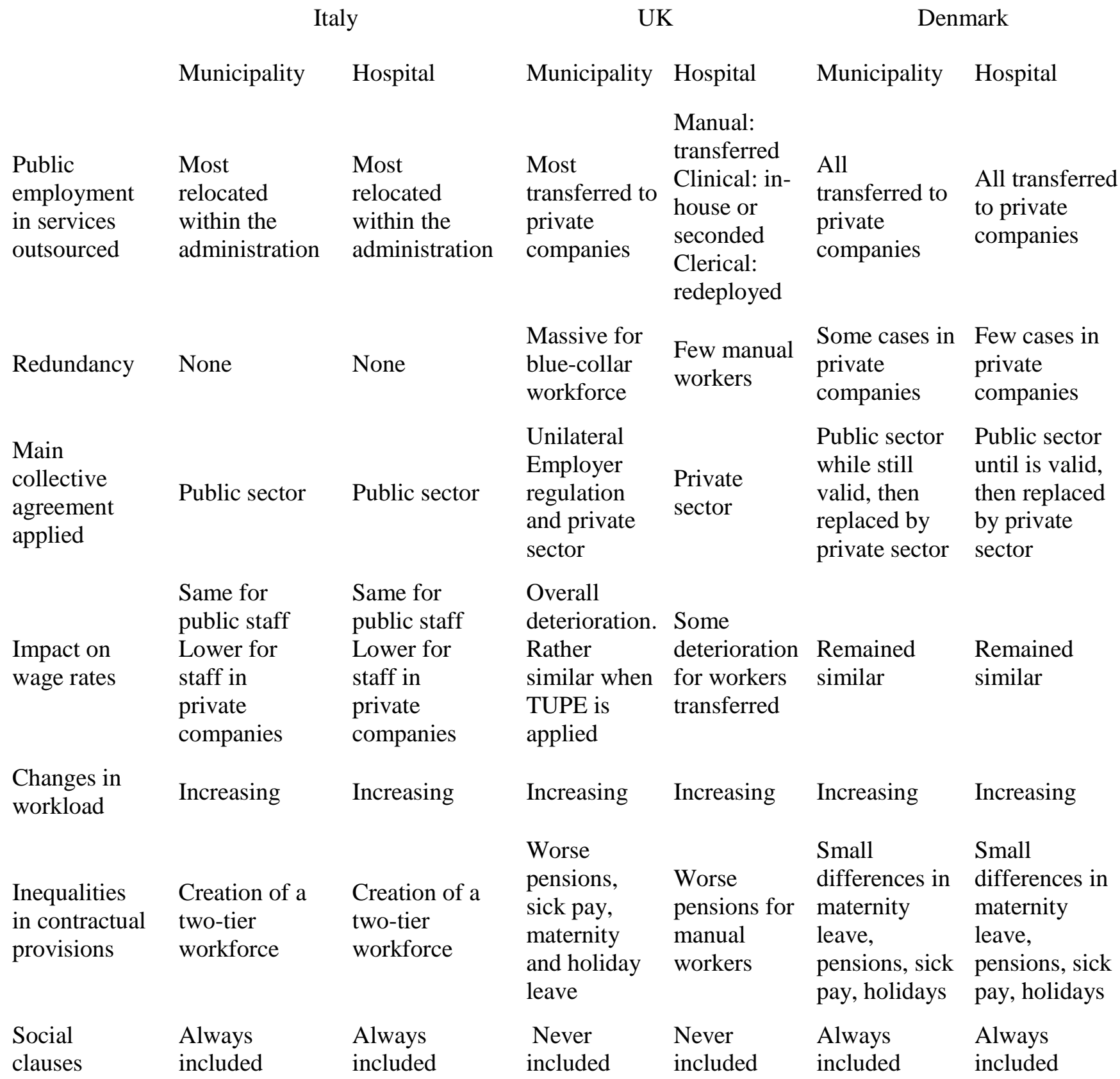

